\title{
All Wealth Is Not Created Equal: Race, Parental Net Worth, and Children's Achievement
}

\author{
JORDAN A. CONWELL (1) AND LEAFIA ZI YE৫
}

Using data from the children of the National Longitudinal Survey of Youth 1979 cohort, spanning 1986 to 2014, we investigated whether White, Black, and Hispanic children whose parents had the same wealth, measured as net worth, have equal math and reading achievement trajectories from age five through fourteen. Black and Hispanic children often had significantly worse scores than same-wealth Whites. We also found racial variation, to the disadvantage of Blacks and Hispanics relative to same-wealth Whites, in measures of family demographic context and financial portfolio composition, both of which research has linked to children's achievement. Whereas previous research has found that structural racial inequality contributes to racial differences in wealth, we find evidence of similar processes in same-wealth comparisons that have potential implications for children's academic success.

Keywords: wealth, race, achievement, assets, debts

One of the most consistent findings in the social science literature on wealth is that wealth is unequally distributed by race, to the disadvantage of Blacks and Hispanics relative to Whites (Conley 1999; Darity et al. 2018; Gittleman and Wolff 2004; Killewald and Bryan 2018; Killewald, Pfeffer, and Schachner 2017; Oliver and Shapiro 2006; Smith 1995; Taylor et al. 2011). Racial wealth gaps are vastly larger than racial income gaps, and racial wealth gaps have markedly increased over the same time period that racial income gaps have remained relatively stable (Percheski and Gibson-Davis 2020; Wolff 2017). Moreover, racial inequalities in other aspects of socioeconomic status (SES), such as income and educational attainment, do not fully account for racial disparities in wealth. Wealth is one measure of the multigenerational and structural nature of racial inequality (Brown 2016; Conley 1999; Herring and Henderson 2016; Oliver and Shapiro 2006), which a single generation's socioeconomic at-

Jordan A. Conwell is assistant professor of sociology and educational policy studies at the University of Wisconsin-Madison, United States. Leafia Zi Ye is a PhD candidate in sociology and an affiliate of the Center for Demography and Ecology at the University of Wisconsin-Madison, United States.

(C) 2021 Russell Sage Foundation. Conwell, Jordan A., and Leafia Zi Ye. 2021. "All Wealth Is Not Created Equal: Race, Parental Net Worth, and Children's Achievement." RSF: The Russell Sage Foundation Journal of the Social Sciences 7(3): 101-21. DOI: 10.7758/RSF.2021.7.3.05. For helpful feedback on this study, we thank Eric Grodsky, Natasha Quadlin, RSF volume editors Christina Gibson-Davis and Heather Hill, and participants at the RSF conference "Wealth Inequality and Child Development: New Evidence for Policy and Practice." Direct correspondence to: Jordan A. Conwell at jaconwell@wisc.edu, 4448 Sewell Social Sciences, 1180 Observatory Drive, Madison, WI 53706, United States.

Open Access Policy: RSF: The Russell Sage Foundation Journal of the Social Sciences is an open access journal. This article is published under a Creative Commons Attribution-NonCommercial-NoDerivs 3.0 Unported License. 
tainments, regardless of how elite or hard-won, often cannot fully erase. Recent policy discussions have also called attention to racial wealth gaps. In 2019, multiple candidates for president offered plans to reduce them, including facilitating homeownership for families of color and "baby bonds" (Astor 2019). In the tumultuous year of 2020, renewed calls for racial justice in many domains of social, economic, political, and cultural life also highlighted the issue.

Household wealth is correlated with children's academic, behavioral, health, and other outcomes (Destin 2013; Hällsten and Pfeffer 2017; Shanks 2007; see also, from this issue, Boen, Keister, and Graetz 2021; Gibson-Davis and Hill 2021; Nepomnyaschy et al. 2021; Miller et al. 2021). As Christina Gibson-Davis and Heather Hill outline in the introduction to this issue, wealth provides child households with resources, security, and class status. Wealth facilitates parents' time and money investments in children, contributes to parents' sense of financial well-being, raises future expectations for children in areas such as schooling, and lowers parental stress. The ways that wealth allows parents to purchase school and neighborhood quality for children - which Gibson-Davis and Hill describe as a secondary mechanism of wealth effects on child development-are especially salient here, given our focus in this article on children's math and reading achievement. Racial disparities in wealth mean that, relative to White children, Black and Hispanic children are less likely to benefit from these processes. Further, because wealth is distinct from income-and unequally distributed by race, net of income-Black and Hispanic children remain less likely to fully benefit from these processes even if their parents have the same income as Whites.

An existing research stream has investigated relationships between race, wealth, and children's school achievement and related outcomes, such as grade retention. This work has often assessed the extent to which average racial disparities in wealth account for average racial gaps in these outcomes, with wealth entered into statistical models after a number of other explanatory factors (Easton-Brooks and Davis 2007; Kaushal and Nepomnyaschy 2009; Orr 2003; Yeung and Conley 2008). This re- search finds that racial wealth disparities may slightly mediate racial gaps in achievement, but wealth accounts for a small share of achievement gaps in these studies.

In this study, we contribute to the literature on race, wealth, and children's achievement by analyzing the math and reading achievement of White, Black, and Hispanic children whose parents have the same wealth (net worth). We make these comparisons at the 25th, 50th, and 75th percentiles of net worth to capture potential variation in patterns of interest across the wealth distribution. Analyses examine the extent to which White, Black, and Hispanic children whose parents have the same position in the wealth distribution have comparable achievement trajectories and comparable access to resources for their academic development. To our knowledge, ours is the first study in the literature on race, wealth, and children's achievement to leverage same-wealth comparisons in these ways.

If we do find such racial achievement gaps between same-wealth children, it would mean that wealth, at least when measured as parental net worth, still does not fully capture racial differences in children's developmental opportunities-indicating the need to search out racial differences between same-wealth families in other factors relevant to children's achievement. To this end, we assess potential racial differences between same-wealth White, Black, and Hispanic families in two areas: (1) family demographic and developmental context characteristics and (2) asset and debt composition of net worth portfolios. Both domains include characteristics of families and households that link parental wealth to children's development (see Gibson-Davis and Hill 2021, this issue). The latter analysis investigates the possibility that Black, Hispanic, and White households reach a given position in the wealth distribution by different pathways. We interpret such differences as due to racially unequal exposure to historical and contemporary structural constraints on certain types of wealth accumulation, such as persistent racial discrimination in the mortgage and housing market (see, for example, Quillian, Lee, and Honoré 2020). Research on race and wealth has leveraged structural perspectives to understand the factors that con- 
tribute to racial differences in wealth, to the disadvantage of Blacks and Hispanics relative to Whites (Brown 2016; Herring and Henderson 2016; Keister 2000). Here, we extend this logic to understand potential racial variation in the pathways that households with children take to attain the same wealth levels and these routes' potential implications for children's developmental opportunities.

We investigate these possibilities using data from the children of the National Longitudinal Survey of Youth 1979 cohort (C-NLSY), spanning from 1986 through 2014. When merged with children's mothers' records from the original NLSY79, the data provide fine-grained, longitudinal information on family financial circumstances. This includes summary parental net worth measures and detailed measures of specific categories of assets and debts, many other measures of children's family demographic characteristics and developmental contexts, and children's math and reading achievement scores. The original NLSY79 sampling frame's racial diversity allows us to track potential differences between Whites, Blacks, and Hispanics. We arrange the data into a child-age panel and use multilevel growth curve modeling techniques to analyze trends of interest for children age five through fourteen.

\section{BACKGROUND}

Racial disparities in wealth are large and persistent (Conley 1999; Darity et al. 2018; Gittleman and Wolff 2004; Killewald and Bryan 2018; Killewald, Pfeffer, and Schachner 2017; Oliver and Shapiro 2006; Smith 1995; Taylor et al. 2011). They have also grown in recent years given the Great Recession's (2007-2009) racially unequal impact on wealth portfolios. Although Blacks, Whites, and Hispanics all lost wealth during this period, Blacks' and Hispanics' wealth declined disproportionately, and Whites and Hispanics (but not Blacks) have recovered much of their losses (Percheski and Gibson-Davis 2020; Taylor et al. 2011; Wolff 2017). In 2004, median Black net worth $(\$ 15,000)$ was less than 10 percent of median White net worth $(\$ 150,000)$. By 2016 , median Black net worth $(\$ 3,400)$ was just over 2.4 percent of median White net worth $(\$ 140,500)$ (Wolff 2017). The Hispanic-White gap in me- dian wealth has remained relatively flat over this period, due to both groups losing wealth around the Great Recession yet being able to recover. In both 2004 and 2016, Hispanic median wealth was approximately one-twentieth that of median White wealth. Wealth gaps between Whites, Blacks, and Hispanics also persist net of socioeconomic status (SES) characteristics such as income (Darity et al. 2018; Smith 1995) and educational attainment (Meschede et al. 2017).

Recent studies have also investigated wealth disparities among households with resident children, our study's target population (Gibson-Davis and Percheski 2018; Percheski and Gibson-Davis 2020). This work demonstrates that wealth inequality's magnitude and over-time trend differs between households with and without resident children, including when it comes to racial wealth gaps. Relative to the Black-White wealth gap among households without children, that among child households was already larger in the early 2000s and increasing before the Great Recession (Percheski and Gibson-Davis 2020). By 2016, Black households with children held one cent of wealth per dollar of White wealth, relative to eight cents per dollar among households without resident children. In contrast, among Hispanics, the two gaps followed similar trends until the 2013 to 2016 period, when Hispanic child households made gains relative to their White peers but Hispanic childless households did not; by 2016, Hispanic households with children held eight cents of wealth per dollar of White wealth, relative to two cents per White dollar among households without resident children (Percheski and Gibson-Davis 2020).

Many scholars have interpreted racial differences in wealth as primarily due to manifestations of race's multigenerational and structural influence across various domains of social, economic, and political life (see Bonilla-Silva 1997). These processes disadvantage Blacks and Hispanics and advantage Whites, with both advantages and disadvantages compounding across generations. Cedric Herring and Loren Henderson (2016) summarize this interpretation of wealth gaps as focused on racial discrimination and unequal opportunity in three interrelated 
markets-labor, credit, and housing. In the labor market, audit studies have demonstrated that discrimination hampers Blacks and Hispanics' labor-market participation and types of jobs they are offered relative to Whites who have comparable human and social capital backgrounds, such as equal educational attainment (Gaddis 2015; Pager, Western, and Bonikowski 2009). These labor-market processes contribute to racial income gaps that leave Blacks and Hispanics with, on average, less money than Whites to save or invest. In the credit market, among other instances of unequal opportunity, Blacks and Hispanics face discrimination in obtaining loans for small businesses, a potential way to build wealth (Blanchflower, Levine, and Zimmerman 2003; Cavalluzzo and Cavalluzzo 1998). In the housing market, Blacks and Hispanics also have comparatively lower rates of homeownership than Whites, and, among owners, lower wealth returns to their properties (see Killewald 2013), attributable in part to racial discrimination in mortgages and housing that disadvantages Blacks and Hispanics relative to Whites (Quillian, Lee, and Honoré 2020).

Other structural processes that do not fall as neatly within the three markets typology also contribute to racial disparities in wealth. One of many consequences of multigenerational wealth inequality in families is that, even among those who are well off, Blacks and Hispanics are more likely than similarly advantaged Whites to provide financial support to less well-off kin (Heflin and Pattillo 2006), and these processes have been found to contribute to the Black-White wealth gap (O'Brien 2012). Racial disparities in the likelihood of having an incarcerated family member, to the disadvantage of Blacks relative to Whites, also contribute to Black-White wealth gaps (Sykes and Maroto 2016). Black and Hispanic children are more likely than White children to grow up in single parent households (McLanahan and Percheski 2008), implying the possibility that Black and Hispanic fathers may be more likely than White fathers to have unsecured debt in the form of child support arrears, which decrease wealth and are negatively correlated with children's socioemotional outcomes (see Nepomnyaschy et al. 2021, this issue).
Race, Wealth, and Children's Achievement A number of studies have investigated wealth's role in Black-White and Hispanic-White gaps in children's K-12 educational outcomes. This work has often assessed the extent to which average racial disparities in wealth account for average racial gaps in these outcomes, net of a number of other explanatory factors, including parental SES characteristics such as education and income (Easton-Brooks and Davis 2007; Kaushal and Nepomnyaschy 2009; Orr 2003; Yeung and Conley 2008). On balance, this work indicates that racial wealth disparities may slightly mediate racial gaps in achievement, as well as related outcomes like grade retention. However, the share of racial gaps that wealth accounts for in these studies is small.

Studies by Jean Yeung and Dalton Conley (2008) and Amy Orr (2003) exemplify this approach and its results using data on math and reading achievement from children in a similar age range to our sample. Using data from the Panel Study of Income Dynamics on children between the ages of three and twelve, Yeung and Conley find that significant Black-White gaps in children's reading and math scores were fully accounted for by background characteristics including parental education, occupation, and income, and grandparent's education, which they entered into statistical models before wealth. Despite Black-White achievement gaps being explained prior to the entry of wealth variables, Yeung and Conley find that, net of other variables, some forms of wealth had significant effects on children's achievement at the conditional mean, with liquid and income-producing assets, such as stocks and mutual funds, being particularly beneficial and debts being detrimental, particularly for the math scores of the older age group (six through twelve) in their sample. Orr came to a similar group of conclusions using data from the National Longitudinal Survey of Youth 1979 Children and Young Adult Study (C-NLSY), a data set covering children born to women in the National Longitudinal Study of Youth 1979 cohort (NLSY79). In analyses of math scores of children aged five through fourteen, background characteristics entered into statistical models prior to wealth largely explained the BlackWhite math gap; wealth did little to further ex- 
plain the gap; and income-producing assets were positively and significantly associated with children's achievement at the conditional mean, net of many other covariates, but nonincome-producing assets (homes and vehicles) were not.

We contribute to the literature on race, wealth, and children's achievement by shifting the axis of comparison to racial achievement gaps between children whose parents have the same wealth. Whereas previous research in this area has often considered parental wealth after a host of other factors, we foreground wealth by comparing the achievement of White, Black, and Hispanic children whose parents have low, middle, and high wealth. Our comparisons are motivated by the observation that disparities in wealth by race are one of the most stubborn vestiges of multigenerational and structural racial inequality. Thus, it seems reasonable to assume that White, Black, and Hispanic children whose parents have the same or a similar position in the wealth distribution will have relatively comparable access to resources for their academic development and, as a result, relatively comparable achievement.

However, if we do find racial achievement gaps between same-wealth children, it would mean that wealth, at least when measured as parental net worth, still does not fully capture racial differences in children's developmental opportunities-indicating the need to search out racial differences between same-wealth families in other factors relevant to children's achievement. To this end, we first assess racial differences at our three focal wealth levels in a set of family demographic characteristics and measures of children's developmental contexts. These variables operationalize a number of the hypothesized mechanisms for household wealth's effects on children's outcomes that Gibson-Davis and Hill outline in the introduction-particularly resources, class status, parental stress, and parental warmth and sensitivity.

The NLSY data we use contain measures of parental net worth (our primary measure of wealth), as well as detailed variables for the asset and debt components that make up net worth. This information allows us to subsequently investigate the extent to which there are racial differences in same-net-worth fami- lies' asset and debt portfolios. Such differences may also contribute to racial achievement gaps between children whose parents have the same wealth. As reviewed, liquid and incomeproducing assets are positively correlated with children's achievement (Orr 2003; Yeung and Conley 2008), net of other factors. Both Orr (2003, see table 1) and Yeung and Conley (2008, see table 1) find that, on average, Blacks have substantially fewer or lower levels of these types of assets than Whites (see also Keister 2000). It is less clear how such differences will play out in same-wealth comparisons, and those studies' samples did not include Hispanics. However, it is possible that Blacks' and Hispanics' wealth portfolios contain fewer of these types of assets than those of same-wealth Whites.

If, at a given level of net worth, Blacks and Hispanics have fewer assets than Whites, it would imply that they also have fewer debts. Yeung and Conley (2008) find that, on average, Whites were almost twice as likely as Blacks to have debt (a summary measure of all debts other than mortgages) and held almost three times as much of it, although this debt was negatively correlated with children's achievement, net of other factors. The same caveats noted above apply to how those trends could be borne out in our analyses. Further, the distinction between good and bad debt (see Gibson-Davis and Hill 2021, this issue, figure 4) is also relevant. Certain types of debt may, under ideal (nonpredatory) circumstances, aid children's development. Mortgage debt, for example, could allow a family to reside in a high-quality public school's catchment area that they otherwise would not be able to access.

\section{This Study}

To summarize, racial disparities in wealth are vast and long-standing. Black and Hispanic children are substantially less likely than White children to reap the child development benefits of parental wealth. A number of studies have investigated the extent to which racial differences in parental wealth account for average racial achievement gaps. However, we are not aware of any that have investigated racial achievement gaps between children whose parents have the same wealth. In this study, we track the achievement trajectories, from age 
five to fourteen, of White, Black, and Hispanic children whose parents have low (25th percentile), middle (50th percentile), and high (75th percentile) wealth. We also descriptively assess two sets of potential explanations for any racial achievement gaps between same-wealth children. To do so, we investigate racial differences between same-wealth families in characteristics of families (mechanisms of wealth's influence on child development) and their finances (financial portfolio composition).

\section{DATA AND METHODS}

Data for this study come from the National Longitudinal Survey of Youth 1979 Children and Young Adult study (C-NLSY) (Center for Human Resource Research 2009). The study is sponsored by the Bureau of Labor Statistics and conducted by the Center for Human Resource Research at the Ohio State University and NORC at the University of Chicago. C-NLSY is made up of data on children born to the women in the original NLSY79 cohort (see Center for Human Resource Research 2001). In the NLSY79's base year of 1979, data were collected from a nationally representative sample of 12,686 respondents between the ages of fourteen and twenty-two (born between 1957 and 1965). NLSY79 respondents were interviewed annually from the base year through 1994, and in even years since then. Beginning in 1986, NLSY began collecting data on children born to these women, with interviews and assessments occurring every two years.

We restructured the C-NLSY data into a child-age record, drawing on all available outcome and explanatory variable observations for children when they were between the ages of five and fourteen. We did not use multiple imputation because most children had a nonmissing observation on our variables of interest in at least one survey wave between those ages. We adjusted standard errors for the study's complex sampling design. When weighted, the C-NLSY data are representative of children born to the NLSY79's representative sample of women.

\section{Variables}

Our outcome variables are children's Peabody Individual Achievement Test (PIAT) math and reading recognition assessment scores from age five through fourteen (for more information on these tests' psychometric properties and administration procedures, see National Longitudinal Surveys n.d.). ${ }^{1}$ The math assessment tested skills ranging from number recognition to geometry. The reading recognition assessment primarily tested children's ability to read aloud words that ranged in difficulty from the preschool to the high school levels (essentially an oral reading exam). We use children's age-adjusted percentile scores on these assessments.

We measure families' wealth with the NLSY's variable for total family net wealth (assets minus debts). We take this variable from children's mothers' NLSY79 records, which we merge onto their children's C-NLSY records. ${ }^{2}$ NLSY created the total net wealth variable based on respondents' answers to a detailed battery of questions about the family's assets and debts. The categories of assets and debts are home value; mortgages and other residential debt; value of farm, business, or real estate; debts of farm, business, or real estate; debt of vehicles; value of stocks, bonds, or mutual funds; value of CDs; value of trusts; value of IRAs; value of $401 \mathrm{ks}$ and $403 \mathrm{bs}$; value of cash savings; value of other assets such as jewelry and collections; and value of all other debts such as credit cards and student loans. This information is available in NLSY79 survey waves from 1985 to 1990, 1992 to 2000, 2004, 2008,2012 , and 2016. In some years, wealth is

1. We do not use children's scores on the PIAT reading comprehension test, also available in the C-NLSY data. Children had to have a high enough score on the reading recognition test to take the reading comprehension test, resulting in small samples of children younger than seven (see National Longitudinal Surveys n.d.). From age seven to fourteen, reading recognition results are substantively similar to those we present for reading recognition.

2. The survey's definition of a family includes those related to the respondent by blood, marriage, or adoption. These variables, therefore, do not capture assets and debts of cohabiting partners who are not married to the mother. 
top-coded at $\$ 50,000$. In these years, we multiplied top-coded values by 1.33 . We capture families' positions in the wealth distribution using (child) age-specific wealth percentiles, based on the distribution of households with children and adjusted for family size. We enter this variable into our models as average percentile across the years when a child was between the ages of five and fourteen. Some of our analyses also use information on specific categories of the assets and debts used to calculate net wealth. Our analyses of families' economic situations also draw on the separate variable for total net family income based on income from the past calendar year, available in all NLSY79 survey waves.

Other explanatory variables include family demographic characteristics and children's developmental contexts, which we measure with variables used in previous studies that have used the C-NLSY data to investigate relationships between these factors and children's developmental outcomes (see, for example, Carlson and Corcoran 2001). These variables are child's age, birth order, gender, and birth weight (low or not); whether their father lives in the household; number of children in the household; HOME (Home Observation Measurement of the Environment) score; and mother's age at the child's birth, years of education, CES-D score (a measure of depressive symptoms), Pearlin Mastery Score, and Armed Forces Qualifying Test score.

\section{Analytic Strategy}

Our analysis proceeds in two stages. First, we assess potential racial differences in the relationship between parental wealth and children's achievement with multilevel growth curve models. In these models, years (in age, five through fourteen) are nested within children. The model includes a three-way interaction of race (a vector containing indicator variables for whether a child is White, Black, or Hispanic), average wealth percentile, and child's age. We model the functional form of the relationship between wealth and children's achievement as linear, following previous re- search (Hällsten and Pfeffer 2017). ${ }^{3}$ We generate predictions based on this model, using Stata's margins command, of the math and reading recognition percentile scores of White, Black, and Hispanic children across the parental wealth distribution as they age from five to fourteen.

Second, we provide a set of descriptive analyses to assess potential racial differences, net of wealth, in families' demographic and financial characteristics. We do so by predicting, at the 25th, 50th, and 75th percentiles of average wealth, Whites', Blacks', and Hispanics' means on variables for family demographic characteristics and other aspects of children's developmental contexts and a subset of the assets and debts used to calculate net wealth, plus family income. These predictions come from regression models that successively use each variable (averaged, child age five through fourteen) as the outcome and regress it on an interaction of race and average wealth percentile. We treat the asset and debt variables as percentiles to deal with inflation and related issues. Descriptive statistics for assets and debts, therefore, provide families' ranks in the distributions of those holdings.

\section{RESULTS}

Figure 1 presents histograms, by race, of wealth percentile, averaged across the years when a child was between the ages of five and fourteen. Predictably, relative to White families, Black and Hispanic families are more likely to be found toward the bottom of the wealth distribution and less likely to be found toward the top. The large spikes in Blacks' and Hispanics' wealth percentile distributions are due to reports of $\$ 0$ net wealth. In results presented later in this article, relative to Whites, standard errors of estimates for Blacks and Hispanics increase by a greater magnitude as net worth percentile increases. This is one of our modeling strategy's desirable properties because it reflects uncertainty based on differential coverage, by race, of families at various points in the wealth distribution.

Figure 2 shows side-by-side box plots of the

3. We also tested other functional forms of the relationship between wealth percentile and the achievement outcomes. On balance, fit statistics favored the linear specification (see table A1). 
Figure 1. Histograms of Wealth Percentiles

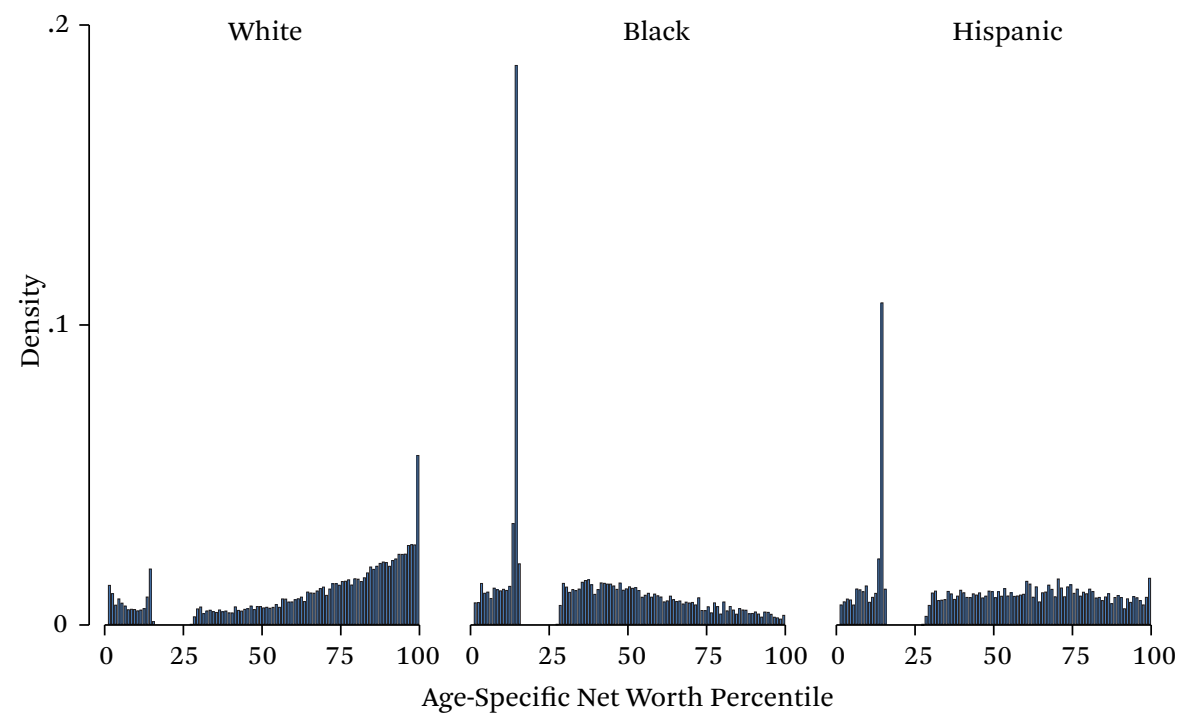

Source: Authors' tabulations based on NLSY and C-NLSY.

Note: Wealth adjusted for square root of household size. Results weighted using the C-NLSY child sampling weight.

Figure 2. Box Plots of Wealth Percentiles by Race Relative to Overall Wealth Percentile
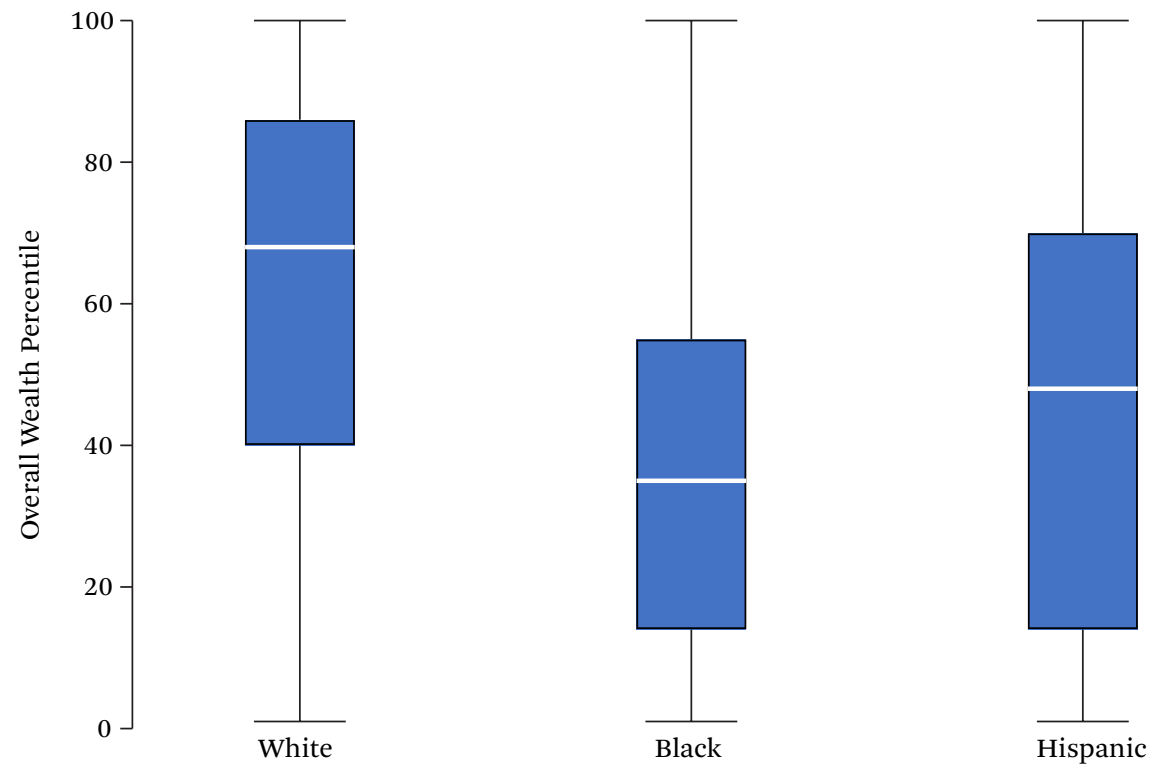

Source: Authors' tabulations based on NLSY and C-NLSY.

Note: Wealth adjusted for square root of household size. Results weighted using the C-NLSY child sampling weight. 
Table 1. Predicted Math, Reading Recognition, and Reading Comprehension Scores

\begin{tabular}{|c|c|c|c|}
\hline Test Subject and Wealth Percentile & $\begin{array}{c}\text { Percentile Scores, } \\
\text { Age Five }\end{array}$ & $\begin{array}{c}\text { Percentile Scores, } \\
\text { Age Fourteen }\end{array}$ & $\begin{array}{c}\text { Gap Change Age } \\
\text { Five to Fourteen, } \\
\text { in Percentiles }\end{array}$ \\
\hline \multicolumn{4}{|l|}{ Math } \\
\hline \multicolumn{4}{|l|}{ 25th percentile } \\
\hline White & 47.26 & 49.38 & - \\
\hline Black & $39.26^{* * *}$ & $35.68^{* * *}$ & 5.70 \\
\hline Hispanic & $38.80^{* * *}$ & $39.62^{* * *}$ & 1.30 \\
\hline \multicolumn{4}{|l|}{ 50th percentile } \\
\hline White & 53.92 & 57.54 & - \\
\hline Black & $44.85^{* * *}$ & $43.08^{* * *}$ & 5.39 \\
\hline Hispanic & $44.23^{* * *}$ & $46.87^{* * *}$ & 0.98 \\
\hline \multicolumn{4}{|l|}{ 75th percentile } \\
\hline White & 60.59 & 65.69 & - \\
\hline Black & $50.44^{* * *}$ & $50.49^{* * *}$ & 5.05 \\
\hline Hispanic & $49.66^{* * *}$ & $54.13^{* * *}$ & 0.63 \\
\hline \multicolumn{4}{|l|}{ Reading recognition } \\
\hline \multicolumn{4}{|l|}{ 25th percentile } \\
\hline White & 55.24 & 51.73 & - \\
\hline Black & 55.14 & $37.93^{* * *}$ & 13.70 \\
\hline Hispanic & $47.11^{* * *}$ & $47.12^{*}$ & -3.52 \\
\hline \multicolumn{4}{|l|}{ 50th percentile } \\
\hline White & 61.24 & 59.38 & - \\
\hline Black & 61.46 & $44.84^{* * *}$ & 14.76 \\
\hline Hispanic & $54.06^{* * *}$ & $53.95^{* * *}$ & -1.75 \\
\hline \multicolumn{4}{|l|}{ 75th percentile } \\
\hline White & 67.23 & 67.02 & - \\
\hline Black & 67.79 & $51.76^{* * *}$ & 15.82 \\
\hline Hispanic & $61.01^{* * *}$ & $60.77^{* * *}$ & 0.03 \\
\hline
\end{tabular}

Source: Authors' tabulation based on NLSY and CNLSY.

Note: Predictions are based on multilevel growth curve models (see model 1 for each subject in table A2). Numbers of observations: math (31,717 observations, 8,513 children); reading recognition $(31,591$ observations, 8,504 children). Gap change is the difference, in percentiles, between the gap at age five and the gap at age fourteen. Significance tests are relative to same-wealth-percentile Whites, based on robust standard errors (not shown).

${ }^{*} p<.05 ;{ }^{* *} p<.01 ;{ }^{* * *} p<.001$

25th, 50th, and 75th wealth percentiles, by race, with the overall (all races) wealth percentiles on the y-axis. The figure provides additional context for our results by showing where households at the 25th, 50th, and 75th percentiles of the overall wealth distribution fall in their own race's income distribution. For example, Black and Hispanic households at the 50th percentile of the overall wealth distribution fall, respectively, at the 75th and 60th percentiles of their own-race wealth distributions. Readers should keep these distributions in mind when considering the results that follow, particularly at relatively high wealth percentiles, where few Hispanic and even fewer Black families are found. For the remainder of the study, all results are based on the overall (all races) wealth percentiles.

\section{Race, Parental Net Worth, and Children's} Math and Reading Achievement

Table 1 shows predicted test scores, by race, for a child whose parents are at 25th, 50th, and 75th 
Figure 3. Predictions on Math, 50th Wealth Percentile

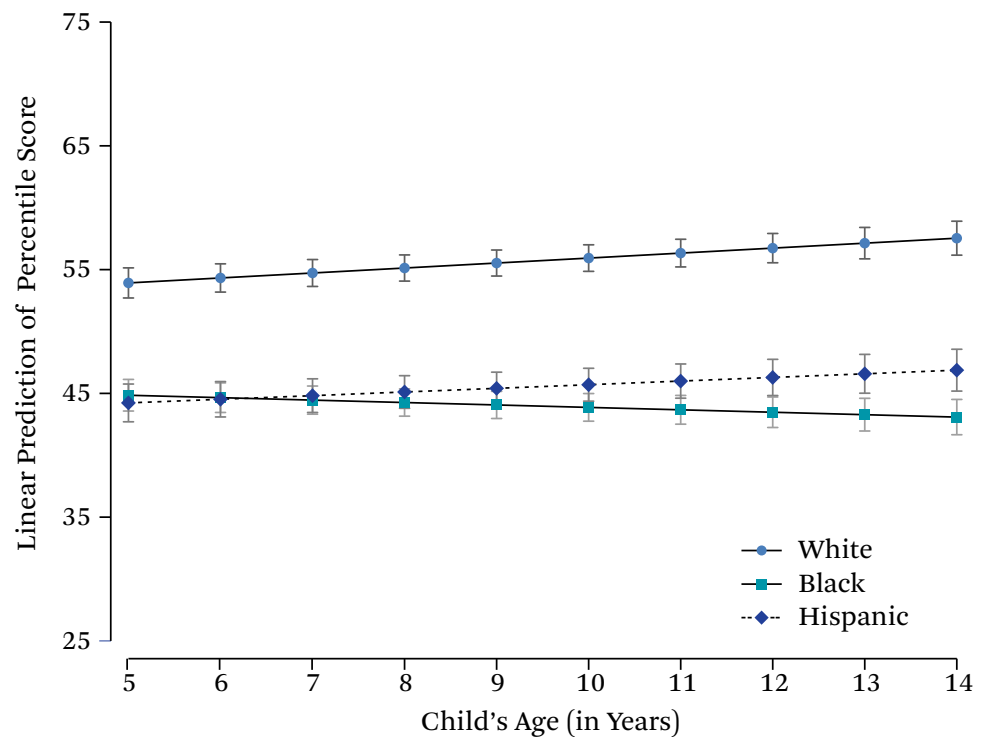

Source: Authors' tabulations based on NLSY and C-NLSY.

Figure 4. Predictions on Reading, 50th Wealth Percentile

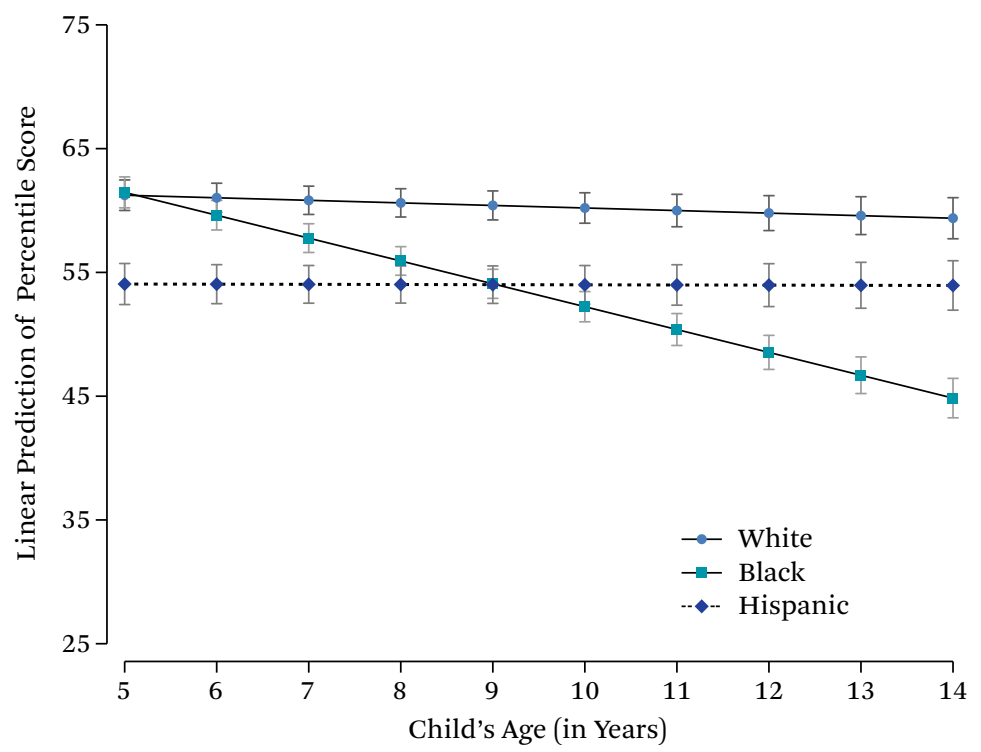

Source: Authors' tabulations based on NLSY and C-NLSY.

percentiles of the wealth distribution, at ages five and fourteen. Table A2 provides the coefficients from the multilevel growth curve models on which these predictions are based. Figure 3 (math) and figure 4 (reading recognition) depict results at the 50th wealth percentile, across all ages from five through fourteen. Two key trends emerge from these results. First, Black and Hispanic children often have significantly lower math and reading scores than 
same-wealth White children at age five, the age typically associated with the start of formal schooling in kindergarten. However, these patterns vary systematically by test subject and racial group. In math, both Black and Hispanic children's scores lag behind those of samewealth Whites. Although all three groups' scores predictably increase as parental wealth increases, a gap of approximately one decile in the achievement distribution is visible at all three focal percentiles ( $p<.001$ for all comparisons). For example, at the median of the parental wealth distribution, White children's math scores are at the 54th percentile, and Black and Hispanic children's scores are both near the 44th percentile. In reading recognition, Black children's scores at age five are statistically indistinguishable from those of same-wealth Whites, but Hispanics' scores are significantly below those of same-wealth Whites at all three focal percentiles. For example, median-wealth Black and White children have reading recognition scores at the $62 \mathrm{nd}$ percentile (difference $N S$ ), while same-wealth Hispanic children's scores are at the 54th percentile ( $p<.001$ versus Whites).

Second, achievement differences between same-wealth White, Black, and Hispanic children change as children age from five to fourteen, but these gap changes are much larger and more deleterious for Blacks than for Hispanics. In math, Black-White gaps between same-wealth children grow by approximately 5 achievement percentiles at each wealth percentile; Hispanic-White gaps grow by no more than 1 achievement percentile. These patterns are even more striking in reading recognition. In that subject, the Black-White gap grows by between 14 and 16 percentiles. Hispanic-White gaps, in contrast, remain stable (75th wealth percentile) or decrease by up to 4 achievement percentiles (25th wealth percentile). Together, these patterns serve to maintain the substantive and statistical significance of Black-White and Hispanic-White achievement gaps between same-wealth children in the comparisons where we observed them at age five, and they create newly significant gaps where we did not (Black-White comparisons in reading recognition).
Race, Parental Net Worth, and

\section{Family Characteristics}

Racial gaps in achievement trajectories between same-wealth children raise the question of the extent to which there are measurable differences between same-wealth White, Black, and Hispanic families that may help account for the gaps. Here, we focus descriptively on two related explanatory domains where we may uncover racial variation, net of wealth-families and their finances. For the first, we assess Black-White and Hispanic-White differences between same-wealth families in measures of family demographic characteristics and other aspects of children's developmental contexts. Table 2 provides these descriptive results for the 25th, 50th, and 75th percentiles of average wealth across the years when the child was age five through fourteen.

Across the wealth distribution, Black and Hispanic families often have significantly different profiles on this set of variables, compared to same-wealth Whites. Notably, these differences are not always to the disadvantage of families of color. At the 25th and 50th percentiles of average wealth, Hispanic (but not Black) mothers have later ages at childbirth than same-wealth White mothers $(p<.05$ for both), and this difference is more than one year at the 25 th wealth percentile. At these wealth levels, therefore, Hispanic children are more likely than White children to benefit from the positive developmental correlates of later maternal age (Duncan, Kalil, and Ziol-Guest 2017; Lopez Turley 2003).

The majority of the other racial differences between same-wealth families that we observe, however, are to Blacks' and Hispanics' disadvantage relative to same-wealth Whites, according to research about the factors' relationships to children's development. For example, at each wealth percentile, Blacks (but not Hispanics) spend a significantly lower proportion of years between the ages of five and fourteen with a father present in the household than samewealth Whites. At the 25th wealth percentile, Blacks' figure is less than one-quarter of this period, relative to just under half for samewealth Whites $(p<.001)$. Blacks' and Whites' proportions both increase with parental wealth. 
Table 2. Family Demographic and Child Developmental Context Characteristics, by Race and Wealth (Average Percentile, Child Age Five to Fourteen)

\begin{tabular}{|c|c|c|c|}
\hline Variable & $\begin{array}{l}\text { White } \\
\text { Mean or } \\
\text { Proportion }\end{array}$ & $\begin{array}{c}\text { Black } \\
\text { Mean or } \\
\text { Proportion }\end{array}$ & $\begin{array}{l}\text { Hispanic } \\
\text { Mean or } \\
\text { Proportion }\end{array}$ \\
\hline \multicolumn{4}{|l|}{ 25th percentile } \\
\hline Mother's age at child's birth & 24.34 & 25.13 & $25.44^{*}$ \\
\hline Child was first born & 0.42 & $0.25^{* * *}$ & $0.27^{* * *}$ \\
\hline Child's birthweight is low & 0.09 & 0.12 & 0.08 \\
\hline Average number of children in the household & 2.23 & $2.72^{* * *}$ & $2.91^{* * *}$ \\
\hline Proportion years father present in the household & 0.46 & $0.22^{* * *}$ & 0.42 \\
\hline Average mother's years of schooling & 11.56 & 11.83 & $10.54^{* * *}$ \\
\hline Mother's armed forces qualifying test score & 40.56 & $18.58^{* * *}$ & $16.97^{* * *}$ \\
\hline Mother's CES-D score & 6.80 & 6.19 & 6.81 \\
\hline Mother's Pearlin Mastery score & 18.43 & $20.47^{* * *}$ & 19.38 \\
\hline Average HOME observation and measurement score & 40.49 & $26.43^{* * *}$ & $29.53^{* * *}$ \\
\hline Child is female & 0.51 & 0.51 & 0.45 \\
\hline \multicolumn{4}{|l|}{ 50th percentile } \\
\hline Mother's age at child's birth & 26.31 & 26.58 & $26.96^{*}$ \\
\hline Child was first born & 0.42 & $0.29^{* * *}$ & $0.30^{* * *}$ \\
\hline Child's birthweight is low & 0.07 & $0.11^{* *}$ & 0.07 \\
\hline Average number of children in the household & 2.33 & $2.57^{* * *}$ & $2.76^{* * *}$ \\
\hline Proportion years father present in the household & 0.62 & $0.44^{* * *}$ & 0.60 \\
\hline Average mother's years of schooling & 12.56 & 12.76 & $11.49 * * *$ \\
\hline Mother's armed forces qualifying test score & 49.35 & $25.65^{* * *}$ & $26.41^{* * *}$ \\
\hline Mother's CES-D score & 5.65 & 5.34 & 5.65 \\
\hline Mother's Pearlin Mastery score & 19.79 & $21.14^{* * *}$ & 20.29 \\
\hline Average HOME observation and measurement score & 49.80 & $36.74^{* * *}$ & $39.83^{* * *}$ \\
\hline Child is female & 0.50 & 0.49 & 0.47 \\
\hline \multicolumn{4}{|l|}{ 75th percentile } \\
\hline Mother's age at child's birth & 28.28 & 28.04 & 28.48 \\
\hline Child was first born & 0.42 & $0.34^{* *}$ & $0.34^{* *}$ \\
\hline Child's birthweight is low & 0.05 & $0.09^{*}$ & 0.06 \\
\hline Average number of children in the household & 2.44 & 2.41 & $2.61^{*}$ \\
\hline Proportion years father present in the household & 0.78 & $0.67^{* * *}$ & 0.77 \\
\hline Average mother's years of schooling & 13.55 & 13.70 & $12.43^{* * *}$ \\
\hline Mother's armed forces qualifying test score & 58.15 & $32.71^{* * *}$ & $35.85^{* * *}$ \\
\hline Mother's CES-D score & 4.50 & 4.50 & 4.50 \\
\hline Mother's Pearlin Mastery score & 21.15 & 21.82 & 21.19 \\
\hline Average HOME observation and measurement score & 59.11 & $47.05^{* * *}$ & $50.13^{* * *}$ \\
\hline Child is female & 0.49 & 0.47 & 0.49 \\
\hline Maximum number of observations & 5,444 & 3,206 & 2,219 \\
\hline
\end{tabular}

Source: Authors' tabulations based on NLSY79 and C-NLSY.

Note: Omitted groups for categorical variables are: child was not first born, child's birthweight was not low, child is male. Significance tests are relative to same-wealth-percentile Whites, based on robust standard errors (not shown).

${ }^{*} p<.05 ;{ }^{* *} p<.01 ;{ }^{* * *} p<.001$ 
But, at the 75th wealth percentile, Blacks still lag behind same-wealth Whites on this measure. White children at that wealth level spend more than three-quarters of their years from five through fourteen with a father present, versus just over two-thirds for same-wealth Black children $(p<.001)$. These patterns imply that, relative to same-wealth Whites, Black children are significantly less likely to reap two-parent family structure's positive effects on math and reading achievement (Carlson and Corcoran 2001). Also notable at each wealth level are Blacks' and Hispanics' significant disadvantages relative to same-wealth Whites on HOME scores, a measure of the quality of children's home environment, and Hispanics' (but not Blacks') significant disadvantages relative to same-wealth Whites in maternal education, of approximately one year at each wealth level. The latter difference indicates that Hispanic children are less likely than same-wealth White children to reap the developmental benefits of maternal education (McLanahan 2004).

In supplemental analyses (not shown) we conducted a counterfactual exercise that predicted Blacks' and Hispanics' math and reading achievement scores at age five if they had the same family demographic characteristics and developmental context characteristics as samewealth Whites. We obtained these predictions by reestimating the growth curve models including all of the family variables as covariates and repredicting Blacks and Hispanics' scores using the means for same-wealth Whites that we obtained in table 2 . In math, adjusted BlackWhite and Hispanic-White gaps between samewealth children remained significant in most comparisons (with the exception of the Hispanic-White gap at the 25th wealth percentile), but Black-White gaps were reduced by approximately 60 percent, and Hispanic-White gaps by between 53 and 70 percent. In reading, adjusting for these factors resulted in substantively large and statistically significant net Black advantages relative to same-wealth Whites, of around 5 achievement percentiles in each comparison, and fully accounted for Hispanic-White gaps. Therefore, racial variation in demographic and developmental context characteristics, net of wealth, plays a con- siderable role in racial achievement gaps between Black, Hispanic, and White children observed at age five.

Race, Parental Net Worth, and

\section{Family Financial Portfolios}

These racial differences in family demographic and developmental context characteristics also bring forward an important puzzle about wealth itself. Why do we observe these differences, often to the disadvantage of families and children of color, net of wealth, considered to be one of the most enduring vestiges of multigenerational and structural racial disadvantage?

Table 3 presents one candidate solution for this puzzle. It shows descriptive statistics for selected components of net worth, by race, at the 25 th, 50th, and 75th wealth percentiles. These descriptive statistics reveal systematic distinctions in how White, Black, and Hispanic families have attained positions at the 25th, 50 th, and 75 th wealth percentiles. Table 3 shows that these distinctions result in substantively large and statistically significant racial differences in families' financial portfolios at a given level of wealth. Moreover, these racial differences vary in magnitude and significance across the wealth distribution.

At the 25th wealth percentile, Blacks (10 percent) and Hispanics (12 percent) are less than half as likely as same-wealth Whites to own residential property, among whom about 25 percent of families are property owners $(p<.001$ for both comparisons). However, among those who own, there are statistically insignificant racial differences in the market value of properties or in debt on the property. Holdings of other assets and debts also differed by race at this wealth level. Both Blacks and Hispanics were approximately half as likely as Whites to have any money assets, such as savings accounts, and three-quarters as likely to have other assets worth more than $\$ 500$, such as jewelry or collections (all differences significant at $p<.01$ or lower). But, among holders of those assets, differences in their values were again not significant.

Families at the 25th wealth percentile also differed by race in their exposure to other debt. 
Table 3. Descriptive Statistics for Selected Components of Net Worth, Plus Income, by Race and Net Worth (Average Percentile, Child Age Five to Fourteen)

\begin{tabular}{cccc}
\hline & White & Black & Hispanic \\
Variable & Mean or & Mean or & Mean or \\
& Proportion & Proportion & Proportion \\
\hline
\end{tabular}

\section{5th percentile}

Own residential property?

0.25

Market value of owned residential property percentile

Amount of mortgages and back taxes owed on

residential property percentile

Any money assets (savings account)?

Amount of money assets percentile

Own any other assets worth more than $\$ 500$ ?

Market value of assets worth more than $\$ 500$ percentile

Any other debt more than $\$ 500$ ?

Amount of other debt more than $\$ 500$ percentile

Household income percentile

\section{0th percentile}

Own residential property?

Market value of owned residential property percentile

Amount of mortgages and back taxes owed on

residential property percentile

Any money assets (savings account)?

Amount of money assets percentile

Own any other assets worth more than $\$ 500$ ?

Market value of assets worth more than $\$ 500$ percentile

Any other debt more than $\$ 500$ ?

Amount of other debt more than $\$ 500$ percentile

Household income percentile

\section{5th percentile}

Own residential property?

Market value of owned residential property percentile

Amount of mortgages and back taxes owed on

residential property percentile

Any money assets (savings account)?

Amount of money assets percentile

Own any other assets worth more than $\$ 500$ ?

Market value of assets worth more than $\$ 500$ percentile

Any other debt more than $\$ 500$ ?

Amount of other debt more than $\$ 500$ percentile

Household income percentile

Maximum number of observations

52.45
19.91

40.49

0.53

20.17

0.39

29.82

0.55

54.03

40.11

0.51

38.99

48.15

0.69

39.39

0.59

44.05

0.48

53.24

54.95

0.78

58.07

55.82

0.85

58.62

0.79

58.28

0.40

69.80

4,650
$0.10^{* * *}$

22.83

34.32

$0.12^{* * *}$

17.94

36.58

$\begin{array}{cc}0.27^{* * *} & 0.27^{* * *} \\ 22.86 & 24.08 \\ 0.32^{* *} & 0.28^{* * *} \\ 28.50 & 25.10 \\ 0.31^{* * *} & 0.34^{* * *} \\ 43.04^{* * *} & 42.50^{* * *} \\ 29.33^{* * *} & 29.84^{* * *}\end{array}$

$0.40^{* * *}$

$0.44^{* * *}$

36.93

$42.13^{* *}$

38.18

46.55

$\begin{array}{cc}0.53^{* * *} & 0.51^{* * *} \\ 39.15 & 40.59 \\ 0.57 & 0.51^{* * *} \\ 42.98 & 41.42 \\ 0.36^{* * *} & 0.37^{* * *} \\ 45.78^{* * *} & 47.01^{* * *} \\ 47.93^{* * *} & 47.60^{* * *}\end{array}$

$0.70^{* * *}$

0.75

$51.04^{* * *}$

58.42

$49.95^{* *}$

56.53

Source: Authors' tabulation based on NLSY79 and C-NLSY.

Note: Significance tests are relative to same-wealth-percentile Whites, based on robust standard errors (not shown).

${ }^{*} p<.05 ;{ }^{* *} p<.01 ;{ }^{* * *} p<.001$ 
Blacks (31 percent) and Hispanics (34 percent) were both significantly less likely than their White counterparts (55 percent) to report other debts more than \$500. Further, among those holding this debt, Blacks and Hispanics held significantly less than Whites: Blacks and Hispanics were just above the 40th percentile, whereas Whites were a decile higher in the distribution, above the median $(p<.001$ for both comparisons). This category of debt conflates types of debt like credit card debt, potentially "bad debt," and educational debt, potentially "good debt." Therefore, relative to Whites, Blacks and Hispanics may be less exposed to bad debt at this wealth level. However, these figures may also signal racial disparities, to the disadvantage of families of color, in access to good debt.

Many of these racial differences persisted at the median of the wealth distribution, alongside predictable changes in groups' means and proportions as wealth increases. Notably, Whites', Blacks', and Hispanics' figures for other debt more than $\$ 500$ were similar at the 25th and 50th wealth percentiles. Using Blacks as an example, supplemental tests (not shown) reveal that the proportion of Blacks reporting this type of debt is significantly higher at the median of the wealth distribution (36 percent) than at the 25 th percentile ( 31 percent, $p<.01$ for comparison), but the amount of debt held is not significantly different (46th percentile at the median versus 43 rd percentile at the 25 th wealth percentile). It is possible that, at the median of the wealth distribution, this type of debt includes a higher proportion of educational and other productive debt.

Patterns are more distinct at the 75th wealth percentile. At this wealth level, Blacks (70 percent), but not Hispanics (75 percent) are significantly less likely to own residential property than Whites (78 percent, $p<.001$ for BlackWhite comparison). Further, at this wealth level, Blacks' residential property has significantly lower value than Whites' (51st percentile for Blacks versus 58th percentile for Whites, $p$ $<$.001), a candidate explanation for their significantly lower level of mortgages and back taxes owed (50th percentile for Blacks versus 56th percentile for Whites, $p<.01$ ). Blacks and Hispanics continue to be significantly less likely than same-wealth Whites to have money assets. However, in a trend not observed at the 25 th or 50th wealth percentiles, Blacks' amount of such assets among holders was significantly lower than Whites' (55th percentile versus 59th percentile, $p<.05)$. We also do not observe racial differences in other debt more than $\$ 500$ at this highest focal wealth level. It remains that, relative to other financial variables, proportions of families reporting such debt and the amount of it among those who have it both change much less across the wealth distribution.

Table 3 also shows the household income percentiles of Whites, Blacks, and Hispanics at the three focal wealth percentiles. Income is distinct from wealth and generally not considered a part of net worth (see Gibson-Davis and Hill 2021, this issue). However, it is a related aspect of families' financial situations that has strong correlations with the developmental environments families are able to provide for children (Bassok et al. 2016; Kalil et al. 2016), as well as children's math and reading achievement outcomes in early childhood and beyond (Reardon 2011; Reardon and Portilla 2016). As the table shows, income is another measure where Blacks and Hispanics are disadvantaged relative to same-wealth Whites. At each of the three focal wealth levels, both groups of color report significantly lower household incomes than same-wealth Whites.

As was true for family characteristics, these analyses make clear that, even at the same level of wealth, the circumstances of same-wealth White, Black, and Hispanic families differ significantly in ways that matter for children's achievement. In regard to the financial variables in table 3, Whites, Blacks, and Hispanics attain the same positions in the wealth distribution but by different pathways. Relative to same-wealth Whites, Blacks and Hispanics often have significantly fewer assets and significantly fewer debts. The asset side of the ledger includes lower holdings of the liquid assets that research shows are positively correlated with children's achievement net of a host of other factors (Orr 2003; Yeung and Conley 2008).

On the debt side of the ledger, Blacks and Hispanics were significantly less likely than same-wealth Whites to own homes in many 
comparisons, and Blacks (but not Hispanics) often had significantly lower levels of mortgage debt. Blacks at the 75th wealth percentile also owned homes of significantly lower value than same-wealth Whites. We interpret these findings in light of persistent anti-Black and anti-Hispanic discrimination in mortgages and housing. As Lincoln Quillian, John Lee, and Brandon Honoré (2020) show in a metaanalysis of previous research from 1976 through 2016, including experimental audits, Blacks and Hispanics continue to face discrimination relative to Whites in housing market outcomes, such as the number of units they are shown, as well as mortgage market outcomes, such as loan approval and mortgage cost. This work and other studies have pointed to housing's role in Black-White and Hispanic-White wealth gaps (Killewald and Bryan 2016). Here we show that racial differences remain in housing characteristics among households that have the same net worth. Larger Black-White than Hispanic-White differences in some comparisons, such as property value among families at the 75th wealth percentile, are consistent with findings that some forms of housing discrimination have more negative impacts on Blacks than on Hispanics (Quillian, Lee, and Honoré 2020).

Our focus on children's achievement calls attention to these patterns' implications for the Black-White and Hispanic-White achievement gaps between children with same-wealth parents that we have documented above (see table 1, figures 3 and 4). Lower rates of homeownership and lower home values among owners signal that, at a given wealth level, Black and Hispanic families may live in less socioeconomically advantaged neighborhoods than Whites, potentially resulting in fewer developmental opportunities from neighborhoods and schools. Income differences between Black, Hispanic, and White families who have the same net worth-to Blacks' and Hispanics' disadvantage-also provide evidence in favor of such a process. Previous work has demonstrated correlations between parental income and neighborhood and school characteristics, with implications for children's achievement (Owens 2018).

\section{DISCUSSION AND CONCLUSION}

Using data from the NLSY79 and C-NLSY, we investigated possible differences in the achievement trajectories, from age five through fourteen, of White, Black, and Hispanic children whose parents have the same wealth, measured as average net worth over the years when the child was in this age range. We also explored two sets of explanations for any such differences, guided by an explanatory framework holding that there may be racial differences, net of wealth, in (1) families' demographic and developmental context characteristics and (2) their financial portfolios, both of which research links to children's achievement.

Our study brings three main findings forward. First, across the distribution of parental wealth, Black and Hispanic children often have significantly worse math and reading scores than same-wealth Whites by age five, and these disparities often increase through age fourteen, particularly for Black-White comparisons. Second, racial differences are clear between same-wealth families, often to the disadvantage of families of color, in family demographic and developmental context characteristics-measures of some of the mechanisms through which household wealth is related to children's development (see GibsonDavis and Hill 2021, this issue). Third, at a given level of net worth, relative to same-wealth Whites, Black and Hispanic families often have significantly fewer assets and significantly fewer debts. On the asset side of the ledger, such racial differences included Blacks and Hispanics having lower holdings of the liquid assets that research demonstrates are positively correlated with children's achievement net of a host of other factors (Orr 2003; Yeung and Conley 2008). On the debt side, relative to Whites, Blacks and Hispanics were often less likely to own homes, and among owners Blacks had lower property values than Whites at the 75th wealth percentile. These patterns could mean that, relative to same-wealth Whites, Blacks and Hispanics have less access to developmentally advantageous school and neighborhood contexts.

We interpret racial variation in financial portfolios at a given level of net worth as struc- 
tured by opportunities and constraints that disadvantage Blacks and Hispanics and advantage Whites. These include, but are not limited to, historical and contemporary discrimination and inequality in three key markets for wealth accumulation-labor, credit, and housing (Herring and Henderson 2016). Research on racial disparities in wealth demonstrates how, for example, unequal asset ownership (Keister 2000) and housing and mortgage discrimination (Quillian, Lee, and Honoré 2020) contribute to racially disparate opportunities for families to build wealth. We show some differences consistent with these patterns among Black, Hispanic, and White families who reach the same point in the wealth distribution. As a summary measure of parental wealth, net worth may obscure systematic racial disparities in access to assets, such as savings accounts, and debts, such as mortgages, that may garner access to socioeconomically advantaged neighborhoods, which could be beneficial for children's achievement. We believe the analytic vantage point of same-wealth comparisons holds considerable value for future research on race and wealth in a number of areas beyond its implications for children's achievement, which has been our focus here.

These findings and their implications should be considered in light of the study's limitations. First, we observed children's achievement beginning at age five, toward the conclusion of the early childhood period, when developmental trajectories are particu- larly sensitive to inputs, including those related to household wealth. Measures from birth through age five would contribute to better understanding of the processes that result in racial achievement gaps, to the disadvantage of children of color relative to samewealth Whites, in math and reading achievement by age five. Second, the C-NLSY data leave us unable to investigate possible racial differences between same-wealth families in school and neighborhood contexts. Schools, neighborhoods, and the peers children encounter in them are all key mechanisms of the relationship between household wealth and children's developmental outcomes (see Gibson-Davis and Hill 2021, this issue). We also lack data on instances of discrimination and inequality that Black and Hispanic students may encounter within schools. These could depress Black and Hispanic children's achievement relative to that of same-wealth Whites, including within socioeconomically advantaged and racially integrated schools and districts, that is, net of the potential differences in school quality just discussed (see IspaLanda and Conwell 2015; Keels, Durkee, and Hope 2017; Lewis-McCoy 2014; Lewis and Diamond 2015). Further, relative to the family characteristics we assess, school and neighborhoods influences on children's development increase as they age (see Chase-Landsdale et al. 1997), making them highly relevant to children's achievement trajectories from age five through fourteen.

Table A1. Fit Statistics for Alternative Specifications of Wealth in Multilevel Growth Curve Models

\begin{tabular}{llll}
\hline & $\mathrm{N}$ & $\mathrm{df}$ & $\mathrm{BIC}$ \\
\hline Math & & & \\
Wealth & 31,717 & 17 & $285,061.5$ \\
Wealth + wealth-squared & 31,717 & 23 & $285,019.5$ \\
Wealth + wealth-squared + wealth-cubed & 31,717 & 29 & $285,069.5$ \\
Reading recognition & & & \\
Wealth & 31,591 & 17 & $279,640.8$ \\
Wealth + wealth-squared & 31,591 & 23 & $279,655.1$ \\
Wealth + wealth-squared + wealth-cubed & 31,591 & 29 & 279,697 \\
\hline
\end{tabular}

Source: Authors' tabulation based on NLSY79 and C-NLSY. 
Table A2. Coefficients from Multilevel Growth Curve Models

\begin{tabular}{|c|c|c|}
\hline Variable & Math & $\begin{array}{l}\text { Reading } \\
\text { Recognition }\end{array}$ \\
\hline Race $=$ Black & $\begin{array}{l}-3.58 \\
(2.81)\end{array}$ & $\begin{array}{c}6.58^{*} \\
(2.82)\end{array}$ \\
\hline Race $=$ Hispanic & $\begin{array}{c}-6.33 \\
(3.36)\end{array}$ & $\begin{array}{c}-12.05^{* * *} \\
(3.44)\end{array}$ \\
\hline Average net worth percentile, child age 5-14 & $\begin{array}{l}.23^{* * *} \\
(.02)\end{array}$ & $\begin{array}{l}.20^{* * *} \\
(.03)\end{array}$ \\
\hline Black $x$ average net worth percentile & $\begin{array}{l}-.05 \\
(.04)\end{array}$ & $\begin{array}{l}.03 \\
(.05)\end{array}$ \\
\hline Hispanic $\mathrm{x}$ average net worth percentile & $\begin{array}{l}-.06 \\
(.05)\end{array}$ & $\begin{array}{l}.08 \\
(.05)\end{array}$ \\
\hline Child age (years) & $\begin{array}{l}.07 \\
(.19)\end{array}$ & $\begin{array}{l}-.57^{* *} \\
(.22)\end{array}$ \\
\hline Black $x$ child age & $\begin{array}{l}-.67^{* *} \\
(.26)\end{array}$ & $\begin{array}{c}-1.40^{* * *} \\
(.28)\end{array}$ \\
\hline Hispanic $x$ child age & $\begin{array}{l}-.18 \\
(.31)\end{array}$ & $\begin{array}{c}.59 \\
(.34)\end{array}$ \\
\hline Average net worth percentile $x$ child age & $\begin{array}{l}.01^{*} \\
(.00)\end{array}$ & $\begin{array}{l}.00^{*} \\
(.00)\end{array}$ \\
\hline Black $x$ average net worth percentile $x$ child age & $\begin{array}{l}.00 \\
(.00)\end{array}$ & $\begin{array}{l}.00 \\
(.00)\end{array}$ \\
\hline Hispanic $x$ average net worth percentile $x$ child age & $\begin{array}{l}.00 \\
(.00)\end{array}$ & $\begin{array}{l}-.01 \\
(.00)\end{array}$ \\
\hline Child is female & $\begin{array}{l}-.54 \\
(.45)\end{array}$ & $\begin{array}{l}4.82^{* * *} \\
(.48)\end{array}$ \\
\hline Constant & $\begin{array}{l}40.51^{* * *} \\
(2.08)\end{array}$ & $\begin{array}{l}49.72^{* * *} \\
(2.15)\end{array}$ \\
\hline Number of observations & 31,717 & 31,591 \\
\hline Number of groups & 8,513 & 8,504 \\
\hline
\end{tabular}

Source: Authors' tabulation based on NLSY79 and C-NLSY.

Note: Robust standard errors in parentheses.

${ }^{*} p<.05 ;{ }^{* *} p<.01 ;{ }^{* * *} p<.001$

\section{REFERENCES}

Astor, Maggie. 2019. "Kamala Harris and Elizabeth Warren Introduce Racial Equity Plans." New York Times, July 6. Accessed December 1, 2020. https://www.nytimes.com/2019/07/06/us /politics/harris-essence-festival-2020-democrats .html.

Bassok, Daphna, Jenna E. Finch, RaeHyuck Lee, Sean F. Reardon, and Jane Waldfogel. 2016. “Socioeconomic Gaps in Early Childhood Experiences." AERA Open 2(3): 1-22.

Blanchflower, David G., Phillip B. Levine, and David J. Zimmerman. 2003. “Discrimination in the
Small-Business Credit Market." Review of Economics and Statistics 85(4): 930-43.

Boen, Courtney, Lisa A. Keister, and Nick Graetz. 2021. "Household Wealth and Child Body Mass Index: Patterns and Mechanisms." RSF: The Russell Sage Foundation Journal of the Social Sciences 7(3): 80-100. DOI: 10.7758/RSF.2021 7.3.04.

Bonilla-Silva, Eduardo. 1997. “Rethinking Racism: Toward a Structural Interpretation." American Sociological Review 62(3): 465-80.

Brown, Tyson H. 2016. “Diverging Fortunes: Racial/ Ethnic Inequality in Wealth Trajectories in Middle 
and Late Life." Race and Social Problems 8(1): 29-41.

Carlson, Marcia J., and Mary E. Corcoran. 2001. "Family Structure and Children's Behavioral and Cognitive Outcomes." Journal of Marriage and Family 63(3): 779-92.

Cavalluzzo, Ken S., and Linda C. Cavalluzzo. 1998. "Market Structure and Discrimination: The Case of Small Business." Journal of Money, Credit and Banking 30(4): 771-92.

Center for Human Resource Research. 2001. NLSY79 User's Guide. Columbus: The Ohio State University.

- 2009. NLSY79 Child \& Young Adult Data Users Guide. Columbus: The Ohio State University. Chase-Landsdale, P. Lindsay, Rachel A. Gordon, Jeanne Brooks-Gunn, and Pamela K. Klebanov. 1997. “Neighborhood and Family Influences on the Intellectual and Behavioral Competence of Preschool and Early School-Age Children." In Neighborhood Poverty: Context and Consequences for Children, edited by Jeanne BrooksGunn, Greg J. Duncan, and J. Lawrence Abner. New York: Russell Sage Foundation.

Conley, Dalton. 1999. Being Black, Living in the Red: Race, Wealth, and Social Policy in America. Berkeley: University of California Press.

Darity, William, Jr., Darrick Hamilton, Mark Paul, Alan Aja, Anne Price, Anotonio Moore, and Caterina Chiopris. 2018. "What We Get Wrong About Closing the Racial Wealth Gap." Durham, N.C., and Oakland, Calif.: Samuel DuBois Cook Center on Social Equity and Insight Center for Community Economic Development.

Destin, Mesmin. 2013. “Integrating Resource-Based and Person-Based Approaches to Understanding Wealth Effects on School Achievement." Economics of Education Review 33 (April): 171-78.

Duncan, Greg J., Ariel Kalil, and Kathleen M. ZiolGuest. 2017. “Increasing Inequality in Parent Incomes and Children's Schooling." Demography 54(5): 1603-26.

Easton-Brooks, Donald, and Alan Davis. 2007. "Wealth, Traditional Socioeconomic Indicators, and the Achievement Debt." Journal of Negro Education 76(4): 530-41.

Gaddis, S. Michael. 2015. “Discrimination in the Credential Society: An Audit Study of Race and College Selectivity in the Labor Market." Social Forces 93(4): 1451-79.
Gibson-Davis, Christina, and Heather D. Hill. 2021. "Childhood Wealth Inequality in the United States: Implications for Social Stratification and Well-Being." RSF: The Russell Sage Foundation Journal of the Social Sciences 7(3): 1-26. DOI: 10.7758/RSF.2021.7.3.01.

Gibson-Davis, Christina M., and Christine Percheski. 2018. "Children and the Elderly: Wealth Inequality Among America's Dependents." Demography 55 (May): 1009-32.

Gittleman, Maury, and Edward N. Wolff. 2004. "Racial Differences in Patterns of Wealth Accumulation." Journal of Human Resources 39(1): 193-227.

Hällsten, Martin, and Fabian T. Pfeffer. 2017. “Grand Advantage: Family Wealth and Grandchildren's Educational Achievement in Sweden." American Sociological Review 82(2): 328-60.

Heflin, Colleen M., and Mary Pattillo. 2006. “Poverty in the Family: Race, Siblings, and Socioeconomic Heterogeneity." Social Science Research 35(4): 804-22.

Herring, Cedric, and Loren Henderson. 2016. "Wealth Inequality in Black and White: Cultural and Structural Sources of the Racial Wealth Gap." Race and Social Problems 8(1): 4-17. Ispa-Landa, Simone, and Jordan Conwell. 2015. "'Once You Go to a White School, You Kind of Adapt': Black Adolescents and the Racial Classification of Schools." Sociology of Education 88(1): $1-19$.

Kalil, Ariel, Kathleen M. Ziol-Guest, Rebecca M. Ryan, and Anna J. Markowitz. 2016. “Changes in Income-Based Gaps in Parent Activities with Young Children from 1988 to 2012." AERA Open 2(3): 1-17.

Kaushal, Neeraj, and Lenna Nepomnyaschy. 2009. “Wealth, Race/Ethnicity, and Children's Educational Outcomes." Children and Youth Services Review 31(9): 963-71.

Keels, Micere, Myles Durkee, and Elan Hope. 2017. “The Psychological and Academic Costs of School-Based Racial and Ethnic Microaggressions." American Educational Research Journal 54(6): 1316-44.

Keister, Lisa A. 2000. “Race and Wealth Inequality: The Impact of Racial Differences in Asset Ownership on the Distribution of Household Wealth." Social Science Research 29(4): 477-502.

Killewald, Alexandra. 2013. "Return to Being Black, Living in the Red: A Race Gap in Wealth That 
Goes Beyond Social Origins." Demography 50(4): 1177-95.

Killewald, Alexandra, and Brielle Bryan. 2016. “Does Your Home Make You Wealthy?" RSF: The Russell Sage Foundation Journal of the Social Sciences 2(6): 110-28. DOI: 10.7758/RSF.2016.2 .6.06.

- 2018. "Falling Behind: The Role of Inter- and Intragenerational Processes in Widening Racial and Ethnic Wealth Gaps through Early and Middle Adulthood." Social Forces 97(2): 705-40.

Killewald, Alexandra, Fabian T. Pfeffer, and Jared N. Schachner. 2017. "Wealth Inequality and Accumulation." Annual Review of Sociology 43(1): 379-404.

Lewis, Amanda E., and John B. Diamond. 2015. Despite the Best Intentions: How Racial Inequality Thrives in Good Schools. New York: Oxford University Press.

Lewis-McCoy, R. L'Heureux. 2014. Inequality in the Promised Land: Race, Resources, and Suburban Schooling. Stanford, Calif.: Stanford University Press.

Lopez Turley, Ruth N. 2003. "Are Children of Young Mothers Disadvantaged Because of Their Mother's Age or Family Background?" Child Development 74(2): 465-74.

McLanahan, Sara. 2004. “Diverging Destinies: How Children Are Faring Under the Second Demographic Transition." Demography 41(4): 607-27.

McLanahan, Sara, and Christine Percheski. 2008. "Family Structure and the Reproduction of Inequality." Annual Review of Sociology 34(1): 25776.

Meschede, Tatjana, Joanna Taylor, Alexis Mann, and Thomas Shapiro. 2017. “'Family Achievements?': How a College Degree Accumulates Wealth for Whites and Not For Blacks." Federal Reserve Bank of St. Louis Review 99(1): 121-37.

Miller, Portia, Tamara Podvysotska, Laura Betancur, and Elizabeth Votruba-Drzal. 2021. "Wealth and Child Development: Differences in Associations by Family Income and Developmental Stage." RSF: The Russell Sage Foundation Journal of the Social Sciences 7(3): 152-74. DOI: 10.7758 /RSF.2021.7.3.07.

National Longitudinal Surveys. n.d. “National Longitudinal Survey of Youth, 1979, Children and Young Adults: Assessments." Accessed December 1, 2020. https://www.nlsinfo.org/content /cohorts/nlsy79-children/topical-guide /assessments.

Nepomnyaschy, Lenna, Allison Dwyer Emory, Kasey J. Eickmeyer, Maureen R. Waller, and Daniel P. Miller. 2021. "Parental Debt and Child WellBeing: What Type of Debt Matters for Child Outcomes?" RSF: The Russell Sage Foundation Journal of the Social Sciences 7(3): 122-51. DOI: 10 .7758/RSF.2021.7.3.06.

O’Brien, Rourke L. 2012. “Depleting Capital? Race, Wealth and Informal Financial Assistance." Social Forces 91(2): 375-96.

Oliver, Melvin L., and Thomas M. Shapiro. 2006. Black Wealth/White Wealth: A New Perspective on Racial Inequality. New York: Routledge.

Orr, Amy J. 2003. "Black-White Differences in Achievement: The Importance of Wealth." Sociology of Education 76(4): 281-304.

Owens, Ann. 2018. “Income Segregation Between School Districts and Inequality in Students' Achievement." Sociology of Education 91(1): 1-27.

Pager, Devah, Bruce Western, and Bart Bonikowski. 2009. “Discrimination in a Low-Wage Labor Market: A Field Experiment." American Sociological Review 74(5): 777-99.

Percheski, Christine, and Christina Gibson-Davis. 2020. "A Penny on the Dollar: Racial Inequalities in Wealth Among Households with Children." Socius: Sociological Research for a Dynamic World 6(1): 1-17.

Quillian, Lincoln, John J. Lee, and Brandon Honoré. 2020. “Racial Discrimination in the U.S. Housing and Mortgage Lending Markets: A Quantitative Review of Trends, 1976-2016." Race and Social Problems 12(1): 13-28.

Reardon, Sean F. 2011. “The Widening Academic Achievement Gap Between the Rich and the Poor: New Evidence and Possible Explanations." In Whither Opportunity? Rising Inequality, Schools, and Children's Life Chances, edited by Greg J. Duncan and Richard J. Murnane. New York: Russell Sage Foundation.

Reardon, Sean F., and Ximena A. Portilla. 2016. “Recent Trends in Income, Racial, and Ethnic School Readiness Gaps at Kindergarten Entry." AERA Open 2(3): 1-18.

Shanks, Trina R. 2007. "The Impacts of Household Wealth on Child Development." Journal of Poverty 11(2): 93-116.

Smith, James P. 1995. “Racial and Ethnic Differences 
in Wealth in the Health and Retirement Study." Journal of Human Resources 30 (Special Issue): S158-83.

Sykes, Bryan L., and Michelle Maroto. 2016. “A Wealth of Inequalities: Mass Incarceration, Employment, and Racial Disparities in U.S. Household Wealth, 1996 to 2011." RSF: The Russell Sage Foundation Journal of the Social Sciences 2(6): 129-54. DOI: 10.7758/RSF.2016.2.6.07.

Taylor, Paul, Rakesh Kochhar, Richard Fry, Gabriel Velasco, and Seth Motel. 2011. Wealth Gaps Rise to Record Highs Between Whites, Blacks and Hispanics. Washington, D.C.: Pew Social \& Demographic Trends.

Wolff, Edward N. 2017. "Household Wealth Trends in the United States, 1962 to 2016: Has Middle Class Wealth Recovered?" NBER working paper no. 24085. Cambridge, Mass.: National Bureau of Economic Research.

Yeung, W. Jean, and Dalton Conley. 2008. “BlackWhite Achievement Gap and Family Wealth." Child Development 79(2): 303-24. 